The International Journal of Engineering and Science (IJES)

|| Volume || 6 || Issue || 12 || Pages || PP 82-96 || 2017 ||

ISSN (e): $2319-1813$ ISSN (p): $2319-1805$

\title{
Effect of management support and user participation on implementation of information systems success and undergraduate programs performance
}

\author{
Harlinda Lahuddin ${ }^{1)}$ H. Basri Modding ${ }^{2)}$, H. Baharuddin Semmaila ${ }^{3)}$, \\ H. Muchtar Lamo ${ }^{4)}$ \\ 1) (Doctoral Student in the Faculty of Economics, University of Muslim Indonesia) \\ 2, 3, 4) (Faculty of Economics, University of Muslim Indonesia)
}

\begin{abstract}
-
This study was conducted in the Makassar city using of 202 undergraduate programs as a population, total sampling is used as a sampling technique. This study aims to examine the effect of management support and user participation on implementation of information systems success and undergraduate programs performance at private universities. The results of the analysis of Structural Equation Model with AMOS version 21 as a research equipment provides evidence that the management support and user participation has significant effect on Implementation of information systems success. Management support is not significant effect on the undergraduate programs performance. User participation and the implementation of information systems success have a significant effect on the undergraduate programs. Management support and user participation of information systems significant effect on the undergraduate programs as a mediated the implementation of information systems success
\end{abstract}

Keywords - Management support, user participation, information systems success, undergraduate programs performance

Date of Submission: Date, 23-11-2017

Date of Publication: Date 05-12-2017

\section{INTRODUCTION}

The public need for formal education, especially higher education is increasing, making higher education as a strategic sector that is expected to produce qualified human resources. A competitive circumstances sufficient competition between universities requires educational institutions and institutional attention to educational quality and high performance so that capable and excels in the competition. Universities should undertake a precaution to the face of increasingly competitive and responsible to explore and enhance all aspects of its services. Competition between universities is getting tougher, both Public Universities (PTN) and Private Universities (PTS), but PTS face a tougher challenge, because in addition must meet accreditation standards, should also consider the quality aspects PTS. The existence of a college is not solely dependent on the government; rather it depends on the assessment of the stakeholders (students, parents, work, government, teachers, support staff, as well as other parties concerned). To be assured of its existence, the college would not want to run quality assurance in higher education were collected. One of the quality assurances to do that is by measuring the performance of the college.

College performance as a benchmark for success that has been achieved by the university, so that is the strategies plan for what to do so that universities can achieve the goals that have been set. The performance of an organization can be viewed from different perspectives depending on the characteristics of each organization. Performance of the organization has always been a measure of success of the organization's activities, so we need a method that can measure such performance. Performance measurement is a complex and a major challenge for researchers because as a construct, multidimensional performance. Therefore, measurement of performance using a single measurement dimension is not able to provide a comprehensive understanding (Li \& Simerly, 1998; Beal, 2000). Organizational performance is assessed using a multidimensional perspective with the following criteria; productivity based on the effect of the use of systems / information technology on productivity members of the organization, cost reduction, the ability to innovate value added through the use of systems / information technology, the ability of the reactivity of the organization in responding to and exploit the 
opportunities that exist, the response rate to customer needs, the relationship of collaboration to partners working through a level shifting the organization's relationship to a strategic partner of rivalry towards collaboration (Kalika \& Rossinsky, 2003). Assessment of organizational performance requires indicators or criteria to measure it clearly. The performance indicators are quantitative or qualitative measure that describes the level of achievement of a goal or goals that have been set. Performance measurement indicators; include: input indicators (inputs), output indicators (outputs), indicators of outcomes and impact indicators (Mahsun, 2006; Dwiyanto, 2006).

The organization developments, demanding performance measurement method that can be accommodate all aspects of the organization. The method is the Balanced Scorecard, which represents all aspects of the performance measurement that consists of the financial perspective, learning and growth perspective, customers, and internal business processes (Kaplan \& Norton, 1996). The information system becomes very important to improve the performance and targets of an organization and have been integrated into the activities of daily business as well as in academic information systems in a university, the information system of new admissions, finance, operations management, marketing, management resources, or other business functions. Use of information systems in higher education has increased in line with the development of increasingly advanced information technology. By using information systems technology is proven to reduce costs, create work processes more quickly and efficiently, as well as offering a high degree of flexibility (Arvidsson et al., 2014). Similarly, with few private colleges in the city of Makassar, has adopted and implemented a computer-based information system to monitor and assist in the performance so as to improve the quality of work and provide great benefits for college.

Characteristics and patterns of information systems implemented in the organization are constantly progressing, along with the development, information technology and the development needs of the organization against information systems. One popular system information model is a model that was developed DeLone \& McLean (1992), known as Success Model of Information Systems. This model reflects the dependence of the six measures of success of information systems, namely: system quality, information quality, user satisfaction, use, the impact of the individual, and the organizational impact. According DeLone \& McLean (1992) the successful implementation of information systems in organizations (information system success) is one factor that plays an important role in improving the operational performance of the organization. Several previous studies indicate that the rate of successful implementation of information systems in organizations affected by the internal characteristics of information systems applied to the organization, so that will give results that are very diverse (Srinivasan, 1985; Susan \& Holmes, 1991; Rai et al, 2002; DeLone \& McLean , 2003). This indicates that the characteristics and patterns of information systems implemented in the organization is constantly progressing, along with the development of information technology and the development needs of the organization against information systems. Research in the field of successful implementation of information systems in the organization and its relationship to organizational performance is one of the interesting research topics.

\section{Literature Review and Hypothesis Development}

\subsection{Management Support (Contextual factors)}

The use of computer-based information system is expected to speed up the processing of data and information with a high degree of accuracy, and efficiency in the completion of tasks and work in accordance with the responsibility of every member of the organization. Another benefit that can be obtained is a level of accuracy and quality of the decisions made head of the organization, the better, so the end result is the achievement of expected operational efficiency of the company. Use of information systems will not provide maximum results, if not supported by the support of management and organization. The importance of management support and organization in the successful implementation of information systems related to the role and benefits of the use of information systems in the organization.

This is reflected in the pattern of organizational leadership policy to exert pressure and influence on the use of information systems to employees, allocation of organizational resources used for the development, implementation and use of information systems and the provision of various facilities at the organization's information systems. Some studies show the influence of variable top management support and development of information systems to the successful implementation of information systems (Doll, 1985; Purvis et al., 2001). Senior Executives have the authority to influence the use of information systems for various business activities of the organization. Top management will always try to improve the quality of information systems through the provision of facilities in the development of information systems (Thong et al., 1996). According to McKeen \& Guimaraes (1997) top management support is one of the key factors that can be a barrier (critical barrier) in the application of information systems in the organization. 
According to Doll (1985) top management support (senior executives) on the implementation and use of information systems significantly affect the attitude of the user to use information systems and the benefits of information systems (system use) on the organization. In various studies in this area, indicators of top management support to the successful implementation of information systems in organizations can be identified from several concepts, namely the allocation of the organization's resources to the development, implementation and use of information systems (Doll, 1985); and the mobilization of resources and managerial substantial material in the development of information systems, as well as providing support for the use of information systems by the user. These results were confirmed by other researchers, such as Thong et al. (1996) influence on organizational management support to the improvement of the quality of information systems. According to Thong et al. (1996) the higher the level of top management support senior executives it would intensify discussions and meetings in the development of information systems, participate in important decision-making, and always active to monitor the implementation of information systems project. The higher level of management support, the quality of the information system will be higher.

Thong et al. (1996) showed that the management of the organization's support will significantly affect the increase in the facilities provided to the information system and improving the quality of the development of the information system itself. Top management support is defined as the top management understanding of computer systems and the level of interest, support, and knowledge of the information system or computerized (Lee \& Kim, 1999). Top management support in the process of development and organization of information systems in the enterprise information system will improve the user wishes to use the existing information systems and satisfied in using the system. Fung Tjhai Jen (2002) have argued that the greater the support given by top management will improve the performance of the accounting information system due to the positive influence between the support of top management in the process of development of information systems with the performance of the accounting information system.

$\mathrm{H}_{1 \mathrm{a}}$ : Management support will have a significant positive effect on the implementation of information systems success

$\mathrm{H}_{\mathrm{lb}}$ : Management support will have a significant positive effect on the undergraduate programs performance

\subsection{User participation of information systems (User Related Factor)}

Participation wearer as behavioral assignments and activities undertaken or their representatives during the process of development of information systems. Participation is done by the user in the form of tangible personal intervention or user activity in the system development. Information system user is anyone who needs information for decision making. User participation information system is also one of the important factors that affect the successful implementation of information systems. This role is related to the use and development of information systems. User involvement in the development of the information system will improve the quality of information systems. which in turn will increase the satisfaction with the services provided by the information system. Increased satisfaction in using information system will affect the intensity of the use of such information systems. This indicates that the higher the participation of users in the use of information systems, the quality of information systems, the intensity of the use of information systems and satisfaction of use of information systems will be better (Barki \& Hartwick, 1994).

Research conducted by Barki \& Hartwick (1994) indicates that there are some internal factors psychological users of information systems that affect the application of the Executive Information System (EIS) on the organization, the level of participation and the level of involvement. There is a significant relationship between user participations, the level of user involvement with the quality system. Srivihok (1999) conducted a research model development Barki \& Hartwick (1994), and empirically test a model of organization in Australia. Model Executive Information Systems Implementation Success (EIS Implementation Success) developed by Srivihok (1999) is an elaboration of the three models of previous studies, namely: Behavioral-Additional Theory (Kappelman \& Mc. Lean, 1991), The Model of User Participation, Involvement and Use (Barki \& Hartwick, 1994) and Information System Success Model (DeLone \& McLean, 1992).

Srivihok (1999) indicates that the user involvement as a moderating variable has a low correlation to the success of information systems of all variables, namely the quality system; quality information; as well as service quality. Scientific contributions given by Srivihok (1999) are a pattern of relationships and the effect of variable levels of participation (user participation), the level of involvement and attitude information system users. The study results Sabherwal et al. (2006) showed that the characteristic of the users of information systems has an important role in the successful implementation of information systems in the organization. The implementation of information systems success in organizations affected by internal factors of users through the dimensions of user experience, training undertaken, attitude of users and user involvement. Lindrianasari (2001) using BAT-IS model approach in researching the successful implementation of information systems in various businesses in Indonesia. The results of these studies indicate that there are two variables that are strong enough 
in relation to the successful implementation of an enterprise information system, which is user participation and user skill levels in the field of information systems. Research conducted by Wildoms Sahusilawane (2014), the results are declared variable user participation in the development of Information Systems significantly influence the performance of Accounting Information Systems. This is because users are often involved in the development of automated systems so that users feel satisfied with their involvement in the development of the system. The involvement of users of information systems (user related factors), the participation of the use of information systems is one of the external factors that influence the successful implementation of information systems in the organization.

$\mathrm{H}_{2 a}$ : User participation of information systems will have a significant positive effect on the implementation of information systems success

$\mathrm{H}_{2 b \text { : }} \quad$ User participation of information systems will have a significant positive effect on the undergraduate programs performance

\subsection{Information systems success}

Information systems (IS) can be defined as a set of formal procedures where data is collected, processed into information, and distributed to users (Hall, 2001). The influence of the current technological developments are so rapid, therefore, today every organization considers that the information system is very important for the survival of the company. Progress microcomputers and software technology and information systems used by business organizations as a tool to improve organizational performance. Successful implementation of the information system is influenced by many complex factors. A failure in the implementation of an information system by Jogiyanto (2007) is divided into two aspects. The first is the technical aspects, the aspects related to the system itself which is the technical quality of the information system. While the second aspect is the non technical aspects, non technical failures related to the user participation of information systems that cause users unwilling or reluctant to use information systems that have been developed.

Researchers have been widely developed a model of success of an information system, one of the popular models is the model developed by DeLone \& McLean (1992), known as Implementation of information systems success reflects the dependence of the six measures of success of information systems, namely: the system quality, the information quality, user satisfaction, use, the impact of the individual and the organizational impact. The implementation of information systems success is one factor that plays an important role in improving the operational performance of the organization. Indicators are a measure successful implementation of information systems in an organization is the quality system, the quality of information, the benefits of the use of the system, user satisfaction, and the effect on individuals and organizations (DeLone \& McLean, 1992).

The implementation of information systems success in the organization in the future require a classification type and the type and characteristics of the information system that is used, in accordance with the rate of growth needs of the organization and development of computer technology. Characteristics and types of information systems that include: scope of the technological level of information systems (aspect of IT use); scope of information system applications (such as: warehouse system, banking system, insurance system, etc.); scope of the use of information system applications (organization, divisions, units and sub-units); scope and characteristics of the development of information systems (IT staff, vendors, software houses, etc.) (Seddon et al., 1999).

$\mathrm{H}_{3:}$ Implementation of information systems success will have a significant positive effect on the undergraduate programs performance

\subsection{Undergraduate programs performance}

Performance has become popular very interesting word in public management. The concept is basically the performance can be viewed from two aspects, namely the performance of employees (individuals) and organizational performance. Performance is an overview of the level of achievement of the implementation of tasks in an organization, in efforts to achieve the goals, objectives, mission and vision of the organization (Bastian, 2001). Performance is a result to be achieved by workers in the work according to certain criteria that apply for a particular job. Furthermore it is said that the strategy requires organizational performance, environmental, technological, and organizational culture are united (Robins, 2001).

Organizational performance is a function of the interaction between ability and motivation. The corresponding sense there is a close relationship between the individual performance with the institutional performance. In other words if the individual performance better then most probably also be a good organizational performance. Individual performance would be better if he had the skill (skill) is high, are willing to work for pay or are paid in accordance with the agreement, have expectation a better future. From some of the above, the performance can be interpreted as the result of work accomplished by individuals, groups and 
organizations within a certain time based on the standard of work that has been set. Organizational performance is the cumulative of the performance of individual or overall staff, where individual performance is expected to meet organizational goals, which are colored by the individual employee motivation and capabilities in performing work of a burden on the organization. Company as community service organizations need to perform in accordance with their missions, because the performance of the organization or company is the result of all management decisions are made continuously.

Flak \& Dertz (2005) says that some of the factors that determine the success of the performance are (1) the commitment of top management and leadership, (2) the participation of employees and middle managers, (3) the culture of good performance, (4) training and education, ( 5) clarity of vision, strategy and results. Furthermore, as described by Carmona \& Gronlund (2003) that the factors expected to affect the performance of the company, are (1) management leadership, (2) information technology, (3) the organizational structure. Research conducted by Rai et al. (2002) individual impact is the impact of the level of user satisfaction with the usefulness of information (output) of applied information systems within the organization. The conception indicates that an important factor that will cause the user's trust is the benefit of information generated by the system, and not based on the ease of use of the system.

According to Doll \& Xia (1997) describe their individual performance improvement competencies, user motivation, confidence, which will encourage users to always try to improve the knowledge and performance, the so-called user empowerment. User's motivational empowerment is a concept based on the integration with cognitive factors and is a reflection of a task which is run by users of information systems. These factors include the user's authority system, intrinsic motivation, as well as the user's perception of the benefits of the use of information systems. Elitan (2002) showed that the application of information technology in the company's medium and large scale manufacturing in Indonesia were selected at random will have a positive influence on the performance (performance) of the company.

Information technology applied by the respondent company, more in the nature of soft technology, the computer-based information technology to support the methods and computer based information system. According to Grover et al. (1996) implementation of information systems in organizations is done to gain a strategic advantage in a constantly evolving environment organization. Research results show that the successful implementation of information systems in organizations affect the improvement of organizational performance. Research conducted by King \& Teo (1996) the successful implementation of information systems in the organization will improve organizational performance. Implementation of information systems is also affected by management support in the implementation process and the development of the information system, as well as in its use in the company's operations daily.

$\mathrm{H}_{4 a}$ : Management support will have a significant positive effect on undergraduate programs performance as a mediated the implementation of information systems success.

$\mathrm{H}_{4 b \text { : }} \quad$ User participation of information systems will have a significant positive effect on undergraduate programs performance as a mediated the implementation of information systems success.

\section{Methods}

This study uses a level of explanation is the research that is intended to explain the position of the variables that were analyzed and the relationship between one variable with another variable and tested hypotheses have been formulated. The samples in this study were limited to 202 undergraduate programs at a private university in Makassar. The Structural Equation Modeling with the Analysis of Moment Structures as research equipment

\section{RESUlts}

\subsection{Respondent Characteristics}

Respondents on this research is characterized by gender male number of $146(72.28 \%)$, at a rate of between 36-45 years of ages as much as 76 respondents (37.13\%), respondents generally have a lecturer's academic status as a Assistant Professor as many as 73 respondents (36.12\%), for a Job tenure dominated by Beke fw between 11-20 years that number $92(45.54 \%)$. As for the education level of respondents were stratified characterized by Master's degree 162 respondents $(80.19 \%)$,

Respondents characteristics of is the identity of respondents whose data can be shown in the following table: 
Table 1. Respondents

\begin{tabular}{llcc}
\hline & Characteristics & frequency & percent $(\%)$ \\
Gender & Male & $1402)$ & 72,28 \\
& Female & 56 & 27,72 \\
& $<35$ & 35 & 17,33 \\
Ages & $36-45$ & 75 & 37,13 \\
& $46-55$ & 65 & 32,17 \\
& $56>$ & 27 & 13,36 \\
Lecturer's academic status & Instructor & 62 & 30,68 \\
& Assistant Professor & 73 & 36,12 \\
Job tenure (years) & Associate Professor & 64 & 31,68 \\
& Professor & 3 & 1,42 \\
& $<10$ & 68 & 33,66 \\
Educational level & $11-20$ & 92 & 45,54 \\
& $21-30$ & 30 & 14,85 \\
\hline
\end{tabular}

4.2. Variable description

4.2.1. Management Support $\left(\mathrm{X}_{1}\right)$

Management support is the support of the organization's leaders allocates organizational resources used for the development, implementation and use of information systems, as well as providing managerial support to the use of information systems. Variable management support is measured by five indicators, namely supporting facilities, management influence, authority management, interest in the use and expertise. Results of respondents on average obtained a value of 4.14. The average value and the loading factor shown in the following table:

Table 1. Management Support (Mean, Loading Factor, validity and reliability test)

\begin{tabular}{|c|c|c|c|c|}
\hline $\begin{array}{l}\text { Indicator } \\
\text { variables }\end{array}$ & Mean & validity, & reliability & $\begin{array}{c}\mathrm{LDF} \\
(\lambda)\end{array}$ \\
\hline $\mathrm{X}_{11}$ & 3.85 & 0.695 & & 0.588 \\
\hline$X_{12}$ & 4.10 & 0.741 & & 0.644 \\
\hline $\mathrm{X}_{13}$ & 4.18 & 0.728 & 0.757 & 0.647 \\
\hline $\mathrm{X}_{14}$ & 4.38 & 0.729 & & 0.793 \\
\hline $\mathrm{X}_{15}$ & 4.19 & 0.695 & & 0.550 \\
\hline
\end{tabular}

4.2.2. User participation of information systems $\left(\mathrm{X}_{2}\right)$

User participation is the involvements of users of information systems to use information systems in the completion of tasks and work, as well as participate contribute and opinions in the development and improvement of information systems implemented on the private universities. User participation of information systems is measured by four indicators, namely evaluation, correction of errors, training and usage report. Results of respondents on average obtained a value of 3.97. The average value and the loading factor shown in the following table:

Table 2. User participation information system (Mean, Loading Factor, validity and reliability test)

\begin{tabular}{|c|c|c|c|c|}
\hline $\begin{array}{l}\text { Indicator } \\
\text { variables }\end{array}$ & Mean & validity, & reliability & $\begin{array}{c}\mathrm{LDF} \\
(\lambda)\end{array}$ \\
\hline$X_{21}$ & 3.88 & 0.760 & \multirow{4}{*}{0.802} & 0.503 \\
\hline$X_{22}$ & 3,88 & 0.824 & & 0.675 \\
\hline $\mathrm{X}_{23}$ & 4.03 & 0.812 & & 0.844 \\
\hline$X_{24}$ & 4.08 & 0.788 & & 0.770 \\
\hline
\end{tabular}




\subsubsection{Implementation of information system success $\left(\mathrm{Y}_{1}\right)$}

The Implementation of the success of information systems represent Updated information systems success Models De Lone \& Mc.Lean. Success Models Information System (IS Success Models) by De Lone \& $n$ Mc. Lean (2003) is a model that involves all indicators that influence the performance measurement information system (IS performance) at the organization identified six main factors that affect the measurement of effectiveness and successful implementation of information systems in the organization. Variable success is measured by six indicators, namely quality systems, information quality, service quality, intensity of use, Benefits Usage and Satisfaction of Use. Results of respondents on average obtained a value of 4.07. The average value and the loading factor shown in the following table:

Table 3. Implementation of information system success (Mean, Loading Factor, validity and reliability test)

\begin{tabular}{|c|c|c|c|c|}
\hline $\begin{array}{l}\text { Indicator } \\
\text { variables }\end{array}$ & Mean & validity, & reliability & $\begin{array}{c}\mathrm{LDF} \\
(\lambda)\end{array}$ \\
\hline$Y_{11}$ & 4.24 & 0.657 & \multirow{6}{*}{0.830} & 0.659 \\
\hline$Y_{12}$ & 4,11 & 0.761 & & 0.633 \\
\hline $\mathrm{Y}_{13}$ & 4.00 & 0.728 & & 0.402 \\
\hline$Y_{14}$ & 3.97 & 0.777 & & 0.732 \\
\hline $\mathrm{Y}_{15}$ & 4.00 & 0.776 & & 0.760 \\
\hline$Y_{16}$ & 4.14 & 0.733 & & 0.666 \\
\hline
\end{tabular}

4.2.4. Undergraduate programs performance $\left(\mathrm{Y}_{2}\right)$

Undergraduate programs performance is the achievement of operational results measured undergraduate programs performance according to the perception of leaders and users of information systems to the performance of the study program. Performance study program is measured by four indicators namely financial, customer, internal business process and learning and growth. Results of respondents on average obtained a value of 4.19. The average value and the loading factor shown in the following table:

Table 4. Undergraduate programs performance (Mean, Loading Factor, validity and reliability test)

\begin{tabular}{|c|c|c|c|c|}
\hline $\begin{array}{l}\text { Indicator } \\
\text { variables }\end{array}$ & Mean & validity, & reliability & $\begin{array}{c}\mathrm{LDF} \\
(\lambda)\end{array}$ \\
\hline$Y_{21}$ & 4.03 & 0.753 & \multirow{4}{*}{0.837} & 0.454 \\
\hline$Y_{22}$ & 4,22 & 0,904 & & 0,847 \\
\hline$Y_{23}$ & 4,23 & 0,812 & & 0,825 \\
\hline$Y_{24}$ & 4,27 & 0,855 & & 0,881 \\
\hline
\end{tabular}

\subsection{Goodness of Fit}

Model test results are evaluated based on the goodness of fit indices with the criteria presented models as well as critical values that have compatibility data.

Table 5. Goodness of fit indices overall model

\begin{tabular}{cccc}
\hline Goodness of fit index & Cut-off Value & Results Model $*$ & Description \\
\hline$\chi^{2}-$ Chi-square & small Expected & $150.105<(0.05: 131=158.712)$ & Good \\
Probability & $\geq 0: 05$ & 0121 & Good \\
CMIN / DF & $\leq 2: 00$ & 1.146 & Good \\
RMSEA & $\leq 0: 08$ & 0.027 & Good \\
GFI & $\geq 0.90$ & 0928 & Good \\
AGFI & $\geq 0.90$ & 0896 & Marginal \\
TLI & $\geq 0.92$ & 0.984 & Good \\
CFI & $\geq 0.92$ & 0988 & Good \\
\hline
\end{tabular}

Evaluation of the eight criteria of the model shows the goodness of fitindices only one who do not meet the criteria AGFI, but the value is approaching a critical value, so that the overall model can be said to have been in accordance with the data and can be analyzed further (Ramli \& Sjahruddin,2015).

4.4. Hypothesis testing 
Based on theempirical models proposed in this study can be tested against the hypothesis put forward by testing the path coefficients in structural equation modeling. Testing the hypothesis by looking at the p-value, if the p-value $<0.05$ then the significant influence of variables.The test results are presented in the following table:

Table 6. Hypotheses testing

\begin{tabular}{|c|c|c|c|c|c|c|c|}
\hline \multirow[b]{2}{*}{ Exogenous } & \multicolumn{2}{|l|}{ Variables } & \multicolumn{4}{|c|}{ Standardized } & \multirow[b]{2}{*}{ annotation } \\
\hline & Intervening & Endogenous & $\begin{array}{l}\text { Direct } \\
\text { Effect }\end{array}$ & $\begin{array}{c}\text { Indirect } \\
\text { Effect }\end{array}$ & $\begin{array}{l}\text { Total } \\
\text { Effect }\end{array}$ & P-value & \\
\hline $\begin{array}{l}\text { Management } \\
\text { Support } \\
\left(\mathrm{X}_{1}\right)\end{array}$ & - & $\begin{array}{l}\text { Implementation of } \\
\text { information system } \\
\text { success }\left(\mathrm{Y}_{1}\right)\end{array}$ & 0.335 & 0.000 & 0.335 & 0.001 & $\begin{array}{c}\text { Positive } \\
\text { Significant }\end{array}$ \\
\hline $\begin{array}{l}\text { User participation } \\
\qquad\left(\mathrm{X}_{2}\right)\end{array}$ & - & $\begin{array}{l}\text { Implementation of } \\
\text { information system } \\
\text { success }\left(Y_{1}\right)\end{array}$ & 0.220 & 0.000 & 0.220 & 0.013 & $\begin{array}{l}\text { Positive } \\
\text { significant }\end{array}$ \\
\hline $\begin{array}{c}\text { Management } \\
\text { Support } \\
\left(\mathrm{X}_{1}\right)\end{array}$ & - & $\begin{array}{c}\text { Undergraduate } \\
\text { programs } \\
\text { performance }\left(\mathrm{Y}_{2}\right)\end{array}$ & 0.119 & 0.000 & 0.119 & 0.086 & $\begin{array}{l}\text { Positive } \\
\text { Insignificant }\end{array}$ \\
\hline $\begin{array}{l}\text { User participation } \\
\qquad\left(\mathrm{X}_{2}\right)\end{array}$ & - & $\begin{array}{l}\text { Undergraduate } \\
\text { programs } \\
\text { performance }\left(\mathrm{Y}_{2}\right)\end{array}$ & 0.304 & 0.000 & 0.304 & 0.001 & $\begin{array}{c}\text { Positive } \\
\text { Significant }\end{array}$ \\
\hline $\begin{array}{l}\text { Implementation of } \\
\text { information } \\
\text { system success } \\
\left(\mathrm{Y}_{1}\right)\end{array}$ & - & $\begin{array}{l}\text { Undergraduate } \\
\text { programs } \\
\text { performance }\left(\mathrm{Y}_{2}\right)\end{array}$ & 0.516 & 0.000 & 0.516 & 0.001 & $\begin{array}{c}\text { Positive } \\
\text { Significant }\end{array}$ \\
\hline $\begin{array}{l}\text { Management } \\
\text { Support } \\
\left(\mathrm{X}_{1}\right)\end{array}$ & $\begin{array}{c}\text { Implementation of } \\
\text { information } \\
\text { system success } \\
\left(\mathrm{Y}_{1}\right)\end{array}$ & $\begin{array}{c}\text { Undergraduate } \\
\text { programs } \\
\text { performance }\left(\mathrm{Y}_{2}\right)\end{array}$ & 0.119 & 0.173 & 0.292 & $\begin{array}{c}0.007 \\
* *\end{array}$ & $\begin{array}{c}\text { Positive } \\
\text { Significant }\end{array}$ \\
\hline $\begin{array}{l}\text { User participation } \\
\qquad\left(\mathrm{X}_{2}\right)\end{array}$ & $\begin{array}{c}\text { Implementation of } \\
\text { information } \\
\text { system success } \\
\left(\mathrm{Y}_{1}\right)\end{array}$ & $\begin{array}{c}\text { Undergraduate } \\
\text { programs } \\
\text { performance }\left(\mathrm{Y}_{2}\right)\end{array}$ & 0.304 & 0.114 & 0.418 & $\begin{array}{c}0.029 \\
* *\end{array}$ & $\begin{array}{c}\text { Positive } \\
\text { Significant }\end{array}$ \\
\hline
\end{tabular}

\footnotetext{
**) Sobel test
}

$\mathrm{H}_{1}$ : Management Support have a significant positive effect on Implementation of information system success Management support has significant positive effect on implementation of information system success. This means that the variable management support and indicators provide positive reinforcement on the supporting facilities, management influence, authority management, interest in the use and expertise of the course and contributed very powerful or significant to the successful implementation of information systems. Effect of management support to the implementation of the information system's success can be demonstrated by standardized regression weight estimate value of 0.335 with a positive direction. Influence coefficient is positive, meaning that the high management support, resulting in an increase to the successful implementation of information systems at a private university in Makassar. But it can be evidenced also by the value of the critical ratio $(\mathrm{cr})=2.480>2.00$ and a probability value of $0.001<\alpha=0.05$. This shows that support good management will enhance the success of the implementation of information systems. The first hypothesis testing results prove that the higher the support of management, the successful implementation of information systems will be higher. This indicates that empirically successful implementation of information systems for a course at a private university in the city of Makassar is significantly affected by the variable management support.

This finding supporting with the results of research suggested by Guimares et al. (1997) that the support of top management is one of the key factors that can be a barrier (critical barrier) in the implementation of information systems in the organization. The information system is used by organizations as a means to provide services and support to all activities and activities in achieving the goals set by the organization concerned. Top management will always improve the quality of information systems through the provision of facilities in the development of information systems (Thong et al., 1996; Sambamurthy \& Zmud, 2001). Studies conducted by Doll (1985) that the top management supports to the successful implementation of information systems in organizations can be identified from several concepts, namely (1) Allocation of resources to the development organization, (2) The implementation and use of information systems.

$\mathrm{H}_{2}$ : User participation of information system have a significant positive effect on implementation of information system success 
Effect of user participation on implementation of information system success can be demonstrated by standardized regression weight estimate value of 0.220 with a positive direction. Coefficient effect is positive, meaning that a high user participation, resulting in an increase to the successful implementation of information systems for a course at a private university in Makassar city, but it can be evidenced also by the value of the critical ratio $(\mathrm{cr})=3.321>2.00$ and a probability value of $0.013<\alpha=0.05$. The results of this study empirically supports the concept additional behavioral theory of information system success (BAT-IS) of Kappelman \& Mc. Lean (1991). This theory states that the implementation of the Information Systems organizations affected by the level of participation of users of information systems through variable user involvement as a moderating variable.

These results are consistent with the theory of implementation success executive information systems (EIS Implementation Success) developed by Srivihok (1999). This theory elaborates on the relationship and influence of user participation, the level of user involvement and attitude towards the successful implementation of information systems EIS. According to this theory, the level of participation of users of information systems directly affects the successful implementation of the EIS. Leon A. Kappelman (1991), stating that user participation is defined as the observable behavior of users of information systems in the process of development of information systems; User engagement, as an attitude based on the needs of the user or psychological conditions related to the process and for the resulting information systems; and user engagement, as the set of user behavior and attitude toward information systems and their development.

From the description of the theory can be stated that there is strong empirical evidence to support the conclusion that: (1) User engagement is something different, though related, user participation; (2) The psychological state of user engagement may be more important than the participation of the user in understanding the success of information systems; (3) The theory of behavior-attitude information system success (engagement mediates the relationship between participation with success) (4) Involvement of users during the installation phase is closely related to the success of information systems. This means that the participation of users of information systems is crucial in efforts to achieve the successful implementation of information systems, so if high user participation it will provide any meaningful sense of the successful implementation of information systems.

The description above is supported by the results of research conducted by Barki \& Hartwick (1994 that there are some internal factors psychological users of information systems that affect the application of the executive information system (EIS) on the organization, the level of participation and the level of involvement . this study provides an explanation that internal factors, participation and involvement of members of the organization will give meaning to the successful implementation of information systems. the results of this study support Guimares \& Igbaria (1997), which states that users related factor of users of information systems in the form of user participation information system plays an important role in the implementation of information systems in the organization. These results also reinforce the results of the study Sabherwal et al. (2004) tested the effect of empirical variables user participation information system to the satisfaction of the use of information systems. The results of the researcher's late show that the course (top management) private university in the Makassar city in general tends to already participated in the development and use of information systems.

$\mathrm{H}_{3}$ : Management Support have not significant positive effect on undergraduate programs performance

Effect of Management Support have not significant positive effect on undergraduate programs performance can be evidenced by value of the standardized regression weight estimate 0.119 with insignificant positive direction. The coefficient effect is positive, meaning that the high management support, resulting in an increase undergraduate programs performance at a private university in the Makassar city. Moreover, it can be proved also by the value of the critical ratio $(\mathrm{cr})=1.715<2.00$ and a probability value of $0.086>\alpha=0.05$. The test results prove that the third hypothesis is rejected.

The results of this study supported the theory put forward by Guimares et al. (1997) that the support of top management is one of the key factors that can be a critical barrier in the implementation of information systems in the organization. Top management will always improve the quality of information systems through the provision of facilities in the development of information systems (Thong et al., 1996; Sambamurthy \& Zmud, 2001). Studies conducted by Doll (1985) that the support of top management in the organization can be identified from several concepts, namely (1) Allocation of resources to the development organization, (2) The implementation and use of information systems. The supporting is lower on the provision of facilities management information systems for the exclusion of suspected leaders of each section contained in the university information system procurement planning activities, either in the form of hardware and software information system (Doll, 1985; Sambhamurthy \& Zmud, 2001).

Guimares et al. (1997), that the management support could become an obstacle in the implementation of information systems in an organization if top management does not provide support for the application of 
information systems in the organization will be ineffective and unproductive in the organization's information systems. To that management support is needed in the implementation of information systems, due to the management support it will provide maximum results on organizational performance. This research was supported by the theory which states that the top management is a key success factor information system, if the management does not support the information system will not be productive thus expected performance will not be achieved. Or in other words that without the support of top management, the performance will not be achieved or the support given management does not have a meaningful and real meaning to the undergraduate programs performance.

$\mathrm{H}_{4}$ : User participation of information system have a significant positive effect on undergraduate programs performance

User participation of information system have a significant positive effect on the undergraduate programs performance with a p-value of $0.001>0.05$ with a coefficient of 0.304 . The coefficient indicates that the participation of users of information systems that will encourage the better performance of the study program. User participation is a good information system will improve on undergraduate programs performance; the higher user participation of information system can be support the undergraduate programs performance will be higher. These results support the concept additional behavioral theory of information system success (BAT IS) (Kappelman \& Mc. Lean, 1991). These results are also consistent with the theory of implementation success executive information systems (EIS Implementation Success), which was developed by Srivihok (1999) to develop a model that is on the pattern of the relationship of the effect of variable levels of user participation, the level of involvement and attitude information system users.

The effect of user participation on undergraduate programs performance can be evidenced by the standardized regression weight estimate value of 0.304 with a positive direction. The coefficient effect is positive, meaning that high user participation can be increase undergraduate programs performance at a private university in the Makassar city. Can be evidenced also by the value of the critical ratio (cr) $=4.410>2.00$ and a probability value of $0.001<\alpha=0.05$. According to the theory put forward by Barki \& Hartwick (1994) defines the assignment of user participation as the behavior and activities undertaken or their representatives during the process of development of information systems. Participation is done by the user in the form of tangible personal intervention or user activity in the system development. Information system user is anyone who needs information for decision making. User participation information system is also one of the important factors that affect the successful implementation of information systems in order to improve the performance of the study program. This role is related to the use and development of information systems.

User involvement in the development of the information system will improve the quality of information systems. This in turn will increase the satisfaction with the services provided by system information contained on the course at a private university in the city of Makassar. This means that the existing undergraduate programs at private colleges in the city of Makassar, with the participation of the students, faculty, educators, and all related elements provide meaningful sense of the undergraduate programs performance. Research by Lindrianasari (2001) that there are two variables that are strong enough in relation to the successful implementation of an enterprise information system, which is user participation and user skill levels in the field of information systems. The results showed that user participation and user skill levels have a relationship with the successful implementation of information systems in improving organizational performance.

$\mathrm{H}_{5}$ : Implementation of information system success have a significant positive effect on undergraduate programs performance

Effect of implementation of information system success on undergraduate programs performance can be evidenced by the standardized regression weight estimate value of 0.516 with a positive direction. The coefficient effect is positive, meaning that the successful implementation of information systems is high, resulting in an increase in the undergraduate programs performance at a private university in Makassar city. Moreover, it can be proved also by the value of the critical ratio $(\mathrm{cr})=4.603>2.00$ and a probability value of $0.001<\alpha=0.05$. Based on this it can be concluded that the higher the successful implementation of information systems, the performance will be the better course. These results are consistent with the theory put forward King \& Teo (1996) that the successful implementation of information systems in the organization will improve the performance of the organization. Implementation of information systems is also affected by management support in the implementation process and the development of the information system, as well as in its use in the company's operations daily.

Supporting the research by Hitt \& Brynjolfsson (1994) which states that the implementation of information systems in the organization will significantly influence the improvement of organizational performance, i.e. improved productivity, increased customer satisfaction, and increasing profitability. These 
results are also consistent with research (Singam. 2002), which examines the influence of the successful implementation of information systems on organizational performance. An important factor that should be stressed is the quality of the output produced by the information system, in accordance with the user's perception of the benefits derived from the information system. The characteristics that can be identified from the information quality is covering accurate, has a high precision, currency, output reliability, quantitativeness, completeness, conciseness, format, relevance, sufficiency, comparability, and can be understandability.

Another study was also supported by the results of research conducted by DeLone \& Mc.Lean (1992); the successful implementation of information systems in organizations is one factor that plays an important role in improving the operational performance of the organization. This means that the information system gives an important role in improving organizational performance. It is also in line with research Seddon et al. (1999) which states that the successful implementation of the system in the organization in the future requires a classification type and the type and characteristics of the information system that is used, in accordance with the rate of growth needs of the organization and development of computer technology.

$\mathrm{H}_{6}$ : Management support has a significant positive effect on undergraduate programs performance as a mediated the implementation of information systems success.

Effect of management support on undergraduate programs performance as a mediated the implementation of information systems success can be demonstrated by the coefficient of 0.173 with a positive direction. Influence coefficient is positive, meaning that the high management support, resulting in an increase the undergraduate programs performance as a mediated the implementation of information systems success at a private university in the Makassar city. But it can be evidenced also by the values of a probability of $0.007<\alpha=$ 0.05 . The total effect of management supports on undergraduate programs performance as a mediated the implementation of information systems success is 0.292 . The sixth hypothesis testing results prove that, management support positive and significant effect on the undergraduate programs performance as a mediated the implementation of information systems success at a private university in the city of Makassar. Thus the sixth hypothesis is accepted.

Structural approach contingency theory also performed by Singam (2002), Dimensions of quality systems that affect significant is the accuracy of the system, the value of the data currency, response time, turnaround time, accuracy of data, reliability, completeness, the flexibility of the system, and ease of use. According to Goodhue \& Thompson (1995) one of the factors that influence the successful implementation of information systems in organizations are the benefits obtained from the use of information systems (information use). Benefits information reflects the usability factor and the benefits to the output of an information system. Support management on the performance of the study program, through the successful implementation of information systems. The support of management on the performance of the study program through the implementation of information system success is to do with: (1) the provision of facility supporting information systems is the provision of facilities (hardware) and software (software) computers, as well as various other ancillary equipment, both in number and quality, (2) the influence and authority of the leadership and management of the university against the employees are always active to use information systems to complete tasks and work, (3) Interest in the use of information systems, and (4) the expertise of the management of the ability and a good understanding of the use of computer-based information systems.

From the above in accordance with Islamic management as described in the Qur'an "And keep an alert, because the warning surely it is beneficial for those who believe (QS "Adh-Dzariyaat; 55). Meaning that can be learned from the explanation of the verse is that we are then asked to celebrate, because it's actually useful warning to those who believe. This means that the management support necessary to give each other a useful warning in the use of organizational resources with all the amenities that support management can improve organizational performance through the implementation of information systems.

$\mathrm{H}_{7}$ : User participation of information system have a significant positive effect on undergraduate programs performance as a mediated the implementation of information systems success.

Effect of user participation of information system on undergraduate programs performance as a mediated the implementation of information systems success. Can be proven with coefficient of 0.114 with a positive direction, Moreover, it can be proved also by the probability value of $0.029<\alpha=0.05$. Seventh hypothesis testing results prove that the higher the participation of users of information systems it can be increase of undergraduate programs performance as a mediated the implementation of information systems success. This indicates that the empirical performance of the course at a private university in the city of Makassar is significantly influenced by variables user participation through the implementation of information systems information system success. Based on that conception it can be concluded that the undergraduate programs performance at a private university in the Makassar city is not only influenced by internal factors of the 
system (system quality, information quality, service quality, intensity of use, the benefits of the use and satisfaction of use) but also influenced by the variable level the participation of users of information systems. This finding is consistent with the theory as presented by Kappelman \& Mc. Lean (1991), known as the theory of BAT-IS which states that the successful implementation of Information Systems in organizations affected by the level of participation of user participation indirectly through the level of user involvement as moderating variable.

It is also supported by a study conducted by Wildoms Sahusilawane (2014). As a result declared user participation in the development of Information Systems significantly influences the performance of Accounting Information Systems. This is because users are often involved in the development of automated systems so that users feel satisfied with their involvement in the development of the system. Furthermore, Prihantoro (2006) which stated that the effect of the simultaneous support of management and organization, user participation and the successful implementation of information systems information systems contributes to the variation change of organizational performance. His research indicates that the higher the organizational support and participation of users, then the implementation of the information system of insurance on the insurance company in Indonesia will be more successful. The high success of the implementation of the insurance information system will improve the performance of insurance companies. Thus it is obvious that this study confirms previous research in which user participation information system has significant meaning and reality to the performance of the study program through the successful implementation of information systems. Based on the above it can be concluded that the higher the level of participation of users of information systems it will increase the success rate of implementation of the information system operational performance would be the better course. This indicates that empirically participation of users of information systems can significantly affect performance improvement study programs through the implementation of information system success.

From the above explanation in accordance with Islamic management as described in the Qur'an Surah Al-Anfal (46) " And obey Allah and His Messenger, and do not arguing, that causes you to be daunted and lost strength and patience. Allah is with those who are patient" (Surah Al-Anfal, 46). The meaning and the lessons learned from this verse is that obeys Allah and His Messenger and do not be arguing, causing you to be daunted and lost strength and patience. This means that the patient and follow the commands of Allah and His Messenger, and do not arguing or sharpen existing differences of opinion because it will make you tremble and lost strength, to be patient because God is with those who are patient.

\section{CONCLuSion}

A conclusion section must be included and should indicate clearly the advantages, limitations, and possible applications of the paper. Although a conclusion may review the main points of the paper, do not replicate the abstract as the conclusion. A conclusion might elaborate on the importance of the work or suggest applications and extensions.

Management support is applied in the form of supporting facilities, management influence, authority management, interest in the use and expertise conducted by the university given meaningful and significant to the successful implementation of information systems. Participation information system users are applied in the form of evaluation of information systems, error correction, training and use of the report conducted by the university given meaningful and significant to the successful implementation of information systems. Supporting facilities, management influence, authority management, user interest and expertise conducted by the university made a positive contribution but there is significant and evident in efforts to achieve the high undergraduate programs performance.

System quality, information quality, service quality, intensity of use, the benefits of the use and satisfaction of use carried out by the university, given meaningful and significant effect on the performance of the study program. Supporting facilities, management influence, authority management, user interest and expertise conducted by the university is able to provide a real contribution to the undergraduate programs performance as a mediating role the implementation of information systems success. Evaluation of information systems, error correction, training and use of the report conducted by the university given meaningful and significant effect on the performance of the study program through the successful implementation of information systems.

Facility information systems at the private university in the Makassar city are still inadequate and not in accordance with the needs of each program of study. It takes the attention of leaders and top management at the university, to (1) the involvement of every head of study program in the planning and procurement of information systems and a variety of supporting facilities, (2) the suitability of the hardware and various ancillary equipment other, as well as software with the needs, and the scope of assignments and work on any course of study in the university, (3) the provision of the entire information system facilities on each subject in an amount 
sufficient, (4) improve the response the university to demand the replacement and repair of a partial range of equipment and facilities necessary information systems.

It takes a change in the paradigm of university leadership to actively provide advice and disseminate the use of information systems, supporting the exploration and use of information systems to the maximum in accordance with the limits and authorizations held, involving the role of information systems in decision-making, through the use of information systems actively by leader of University. Leaders and top management at a private university in the city of Makassar is expected to: (1) the need to be evaluated at any given period of the information system implemented at the university, (2) the need for advice and opinions to the improvement and development of information systems of the users of information systems on services can be given by the information system, according to the needs of each program of study, (3) the use of information system output is always used as an ingredient for evaluating the performance of the study program.

The successful implementation of information systems contribute significantly to the operational activities of the study program include improving the quality of service to the academic society so that an increase in the number of new students, the operational cost efficiencies and improved rankings course accreditation. Based on those few things that need to be considered by the leadership and top management of private universities in the city of Makassar, which are (1) the completeness and speed of application systems are implemented by universities, (2) the ability and facilities application systems are used, (3) the ability and database management information system used university, and (4) the accuracy of the application system used. The results showed that the model of successful implementation of information systems (IS Success Model Updated) De Lone and Mc. Lean (2003), can be used as a basis for the successful implementation of information systems research. In this study the model of the successful implementation of information systems equipped with variable contextual factors, management support and user related factors, namely the participation of users of information systems. Based on that, the next is expected in other studies in the field of information systems, researchers in exploring the implementation of information systems based on a more complete perspective.

\section{REFERENCES}

[1] Arvidsson, V., Holmstrom, J., \& Lyytinen, K. (2014). Information systems use strategy as practice: A multi-dimensional view of strategic information system implementation and use. The Journal of Strategic Information Systems, 23 (1), 45-61. https://doi.org/10.1016/j.jsis.2014.01.004

[2] Barki, H., \& Hartwick, J. (1994). Measuring user participation, user involvement, and user attitude. MIS Quarterly, 59-82. https://doi.org/10.2307/249610

[3] Bastian, Indra. (2006). A Public Sector Accounting Pengantar.Penerbit Erland. Jakarta

[4] Beal, RM (2000). Competing Effectively: environmental scanning, competitive strategy, and organizational performance in small manufacturing firms. Journal of Small Business Management, 38 (1), 27.

[5] DeLone, WH, \& McLean, ER (1992). Information systems success: The quest for the dependent variable. Information systems research, 3 (1), 60-95.

[6] DeLone, WH, \& McLean, ER (2003). The DeLone and McLean models of information systems success: a ten-year update. Journal of management information systems, 19 (4), 9-30. https://doi.org/10.1080/07421222.2003.11045748

[7] Doll, WJ (1985). Avenues for top management involvement in successful MIS development. MIS Quarterly, 17-35. https://doi.org/10.2307/249271

[8] Doll, WJ, \& Xia, W. (1997). Confirmatory factor analysis of the end-user computing satisfaction instrument: A replication. Journal of Organizational and End User Computing (JOEUC), 9 (2), 24-31. https://doi.org/10.4018/joeuc.1997040103

[9] Dwiyanto, A. (2006). Reform of public bureaucracy in Indonesia. Gadjah Mada University Press.

[10] Ellitan, L. (2002). Technology Adoption, Technology Management and it's impact on Operationail Performance: A Case From Indonesia. Journal of Business and Accounting, 1 (1), 1-22.

[11] Flak, LS, \& Dertz, W. (2005, August). Stakeholder theory and the balanced scorecard to improve the IS strategy development in the public sector. In Proceedings of the 28th Seminar on Information Systems Research in Scandinavia, Kristiansand, Norway.

[12] Goodhue, DL, \& Thompson, RL (1995). Task-technology fit and individual performance. MIS Quarterly, 213-236. . https://doi.org/10.2307/249689 
[13] Grover, V., Jeong, SR, \& Segars, AH (1996). Information systems effectiveness: The construct space and patters of application. Information \& Management, 31 (4), 177-191. https://doi.org/10.1016/S0378$\underline{7206(96) 01079-8}$

[14] Hall, H. (2001). Input-friendliness: motivating knowledge sharing across intranets. Journal of information science, 27 (3), 139-146. https://doi.org/10.1177/016555150102700303

[15] Hitt, L., \& Brynjolfsson, E. (1994). The three faces of the IT value: theory and evidence. ICIS 1994 Proceedings, 20.

[16] Jen, TF (2002). Factors that affect the performance of the accounting information system. Journal of Business and Accounting, 4 (2), 135-154.

[17] Jogiyanto, HM (2007). Behavioral Information Systems. Yogyakarta: Andi Offset, Co. Ltd.

[18] Kalika, VI, \& Rossinsky, G. (2003). Methodology of multi-criteria decision making accounting for uncertainty and some applications. International Journal of Management and Decision Making, 4 (2-3), 240-271.

[19] Kaplan, RS, \& Norton, DP (1996). The balanced scorecard: translating strategy into action. Harvard Business Press.

[20] Kappelman, LA, \& McLean, ER (1991, January). The respective roles of user participation and user involvement in information system implementation success. In ICIS (pp. 339-349).

[21] King, WR, \& Teo, TS (1996). Key dimensions of facilitators and inhibitors for the strategic use of information technology. Journal of Management Information Systems, 12 (4), 35-53. https://doi.org/10.1080/07421222.1996.11518100

[22] Lee, JN, \& Kim, YG (1999). Effect of partnership quality on IS outsourcing success: conceptual framework and empirical validation. Journal of Management information systems, 15 (4), 29-61.

[23] Li, M., \& Simerly, RL (1998). The moderating effect of environmental Dynamism on the ownership and performance relationship. Strategic Management Journal, 169-179. http://www.jstor.org/stable/3094062

[24] Lindrianasari. (2002). Correlation Between expertise and participation and the correlation between participation and other variables in development information system. National Symposium on Accounting. Jakarta.

[25] Mahsun, M. (2006). Public sector performance measurement. Yogyakarta: BPFE.

[26] McKeen, JD, \& Guimaraes, T. (1997). Successful strategies for user participation in systems development. Journal of Management Information Systems, 14 (2), 133-150.

[27] Purvis, RL, Sambamurthy, V., \& Zmud, RW (2001). The assimilation of knowledge platforms in organisasi: An empirical investigation. Organization science, 12 (2), 117-135.

[28] Rai, A., Lang, SS, \& Welker, RB (2002). Assessing the validity of IS success models: An empirical test and theoretical analysis. Information systems research, 13 (1), 50-69.

[29] Ramli, AH, \& Sjahruddin, H. (2015). Building patient loyalty in healthcare services. International Review of Management and Business Research, 4 (2), 391.

[30] Sabherwal, R., Jeyaraj, A., \& Chowa, C. (2006). Information system success: individual and organizational determinants. Management science, 52 (12), 1849-1864.

[31] Sahusilawane, W. (2015). User participation and support Influence on Performance Tops Accounting Information Systems In Government Commercial Bank. Organization and Management Journal, 10 (1), 3743.

[32] Seddon, PB, Staples, S., Patnayakuni, R., \& Bowtell, M. (1999). Dimensions of information systems success. Communications of the AIS, 2 (3Es), 5.

[33] Srinivasan, A. (1985). Alternative measures of system effectiveness: associations and implications. MIS Quarterly, 243-253. https://doi.org/10.2307/248951

[34] Srivihok, A. (1999, January). Understanding executive information systems implementation: an empirical study of EIS success factors. In Systems Sciences, 1999. HICSS-32. Proceedings of the 32nd Annual Hawaii International Conference on (pp. 10-pp). IEEE.

[35] Susan, D., \& Holmes, JG (1991). The dynamics of interpersonal trust: Resolving uncertainty in the face of risk. Cooperation and prosocial behavior, 190. 
[36] Teo, TS, \& King, WR (1996). Assessing the impact of integrating business planning and IS planning. Information \& Management, 30 (6), 309-321. https://doi.org/10.1016/S0378-7206(96)01076-2

[37] Thong, JY, Yap, CS, \& Raman, KS (1996). Top management support, external expertise and information systems implementation in small businesses. Information systems research, 7 (2), 248-267.

Harlinda Lahuddin "Effect of Management Support And User Participation on Implementation of Information Systems Success And Courses Performance." The International Journal of Engineering and Science (IJES), vol. 6, no. 12, 2017, pp. 82-96. 